\title{
ON A VARIANT OF THE JENSEN-MERCER INEQUALITY FOR OPERATORS
}

\author{
A. MatKović AND J. PeČARIĆ
}

Abstract. Some refinements of the Jensen-Mercer inequality for operators are presented. Obtained results are used to refine some comparision inequalities between power and quasiarithmetic means for operators.

Mathematics subject classification (2000): 47A63, 47A64.

Key words and phrases: Jensen-Mercer inequality for operators, index set function, power means, quasi-arithmetic means.

\section{REFERENCES}

[1] T. Furuta, J. Miććć-Hot, J. PeČARIĆ, Y. SEO, Mond-Pečarić Method in Operator Inequalities, Element, Zagreb, (2005).

[2] A. MATKOVIĆ, J. PeČARIĆ, I. PeRIĆ, A variant of Jensen's inequality of Mercer's type for operators with applications, Linear Algebra Appl., 418 (2006), (2-3), 551-564.

[3] A. MatKoviĆ, J. PeČARIĆ, I. PeRIĆ, Refinements of Jensen's inequality of Mercer's type for operator convex functions, Math. Ineq. Appl., 11 (2008), (1), 113-126.

[4] J. E. PeČarić, F. Proschan, Y. L. Tong, Convex Functions, Partial Orderings, and Statistical Applications, Academic Press, Inc. (1992). 